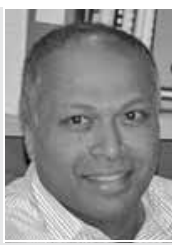

Jaya Kandasamy Senior Lecturer, Faculty of Engineering, University of Technology, Sydney, Australia

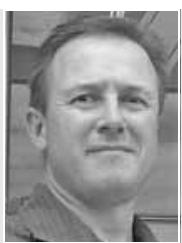

Simon Beecham Professor of Sustainable Water Resossor of Sustainable Water Resources Engineering, School of University of South Australia

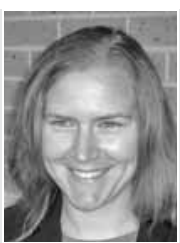

Alison Dunphy Graduate Student, Faculty of Engineering, University of Technology, Sydney, Australia

\title{
Stormwater sand filters in water-sensitive urban design
}

J. Kandasamy ME, PhD, S. Beecham GCHE, ME, PhD and A. Dunphy BE (Hons)

This paper investigates the suitability of sand filters for harvesting and treating stormwater for non-potable reuse purposes. A stormwater sand filtration device was constructed in a small urban catchment in Sydney, Australia. A sand filter is typically used in water-sensitive urban design (WSUD) as a component of a treatment train to remove pollution from stormwater before discharge to receiving waters, to groundwater or for collection and reuse. This paper describes an 18 month field study undertaken to determine the effectiveness and pollutant removal efficiency of a sand filter, and the differences in the pollutant removal efficiency of two grades of sand. A comparison of pollutant removal with previous literature on sand filters showed similar efficiencies but nutrient removal was higher than expected. A further unexpected result was that the coarse filter media performed as well as the fine media for most pollutant types and was superior in suspended solids removal. Improved modelling equations for predicting suspended solids and total phosphorus removal in sand filters are also presented in this paper.

\section{INTRODUCTION}

The guiding principles ${ }^{1}$ of water-sensitive urban design (WSUD) are centred on achieving integrated water cycle management for the development of urban areas. These principles are

(a) reducing potable water demand through water efficient appliance, rainwater and greywater reuse

(b) minimising wastewater generation and treatment of wastewater to a standard suitable for effluent reuse opportunities and/or release to receiving waters

(c) treating urban stormwater to meet water quality objectives for reuse and/or discharge to surface waters

(d) using stormwater in the urban landscape to maximise the visual and recreational amenity of developments.

Sand filtration is commonly used to achieve WSUD as a component of a treatment train to remove pollution from stormwater. Sand filters can remove pollutants such as sediment, nutrients, pathogens, oil and grease from urban runoff. ${ }^{2,3}$

Sand filters, enhanced (peat-sand) filters and compost filters have been used in the past to treat stormwater and wastewater, and are gaining popularity in the United States ${ }^{4}$ and elsewhere as reliable stormwater treatment devices, albeit if properly maintained. Wellcontrolled data are, however, limited on the use of sand filters to treat stormwater. The current paper, using a field study, compares the effectiveness of an open-topped vertical-flow sand filter with pollutant removal efficiencies cited in previous literature.

\section{FIELD SITE AND SAND FILTRATION DEVICE}

The sand filtration device (SFD) is situated in Drummoyne Park, Drummoyne, in suburban Sydney. Drummoyne Park is located approximately $7 \mathrm{~km}$ west of the centre of Sydney and is part of the City of Canada Bay District (approximately $20 \mathrm{~km}^{2}$ in area) and is central in the Sydney Basin. It lies on the southern bank of the Parramatta River estuary, which virtually divides Sydney in half.

The catchment draining to the SFD is 6 ha in size and drains into Five Dock Bay, which is part of Sydney Harbour. The catchment drains generally in a north-west direction. The elevation of the catchment ranges from sea level to about $30 \mathrm{~m}$ above sea-level. The catchment gradients are relatively steep, with an average slope of 4\%. The upper reaches of the catchment comprise commercial and residential land use with three principal roads. The lower areas of the catchment include parkland and recreational areas extending to the foreshores of the Bay. This type of redevelopment (mixed land use) is common in Sydney and has led to increased stormwater runoff owing to the increased proportion of impervious area. ${ }^{3}$

The SFD at Drummoyne Park is an off-line device and was designed to treat the pollution in the first flush. A first flush is said to occur when the first portion of the discharged volume contains most of the pollutant load that is transported during the total storm event. ${ }^{5}$ By intercepting this volume, a large portion of the pollution load may be captured before discharge into the receiving waters. The first flush effect is a characteristic of smaller catchments and is less defined in larger catchments, owing to the buffering effect from various sub-catchments.

The SFD consists of several components including a diversion pit on the main stormwater pipeline, a gross pollutant trap located within the inlet pit, an above-ground storage basin, two sand filter compartments and a monitoring pit at the filter outlet (Figs 1 and 2). The diversion pit diverts stormwater discharges up to the 6 month average recurrence interval (ARI) event (from a rainfall event of approximately $28 \mathrm{~mm} / \mathrm{h}$ ) to the sand filtration compartments. An orifice plate within the diversion pit regulates the flow diverted to the SFD. The gross pollutant trap is a litter basket and provides pre-screening of stormwater to remove gross pollutants and gravel. This helps prevent clogging of the SFD. 


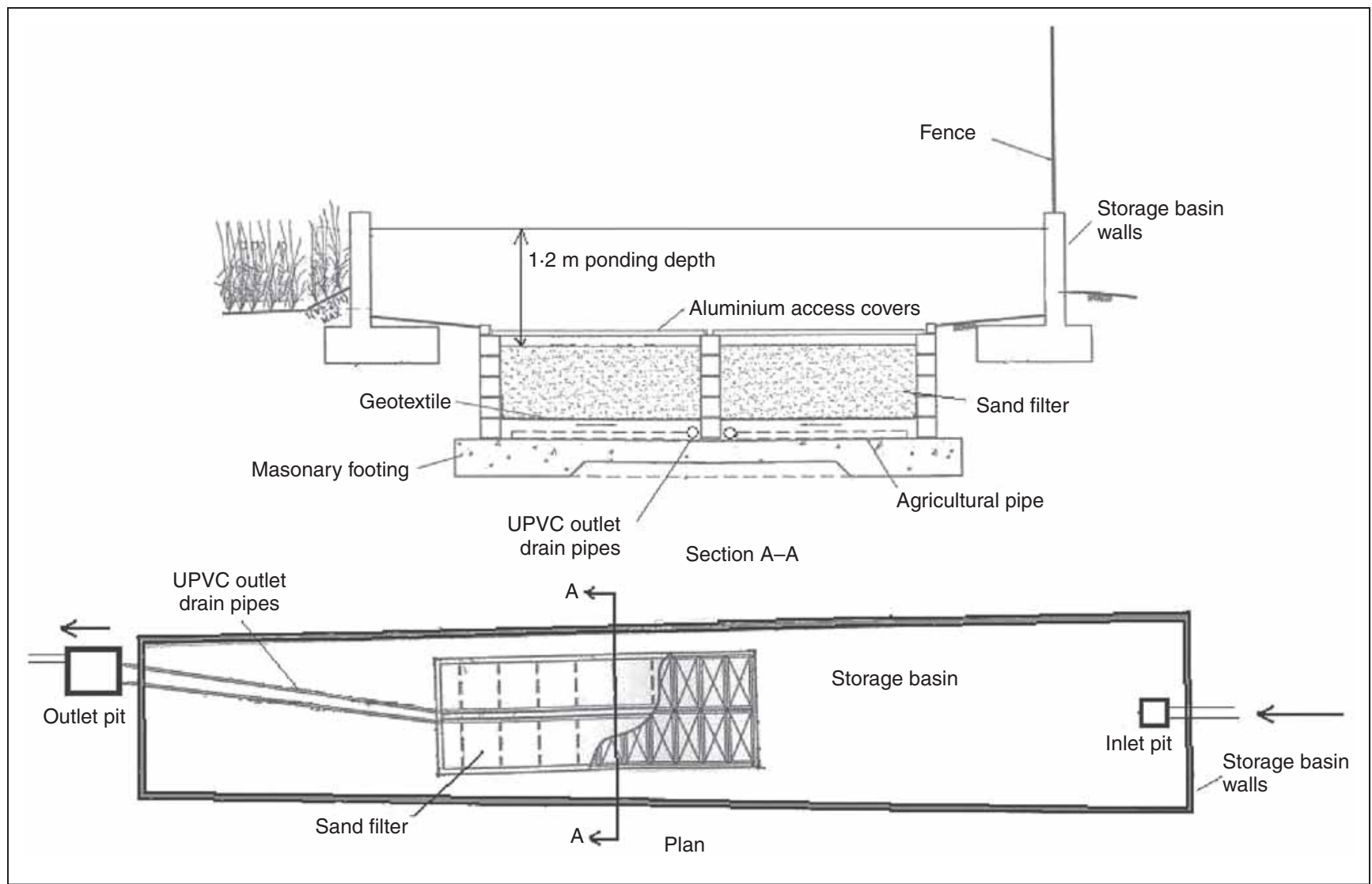

Fig. I. Schematic view of SFD

The surcharge pit provides access to the stormwater inflow for monitoring and directs the stormwater into the above-ground storage basin. The above-ground storage basin provides storage for the first half of the 6 month (ARI) runoff volume. By providing up to $1 \mathrm{~m}$ depth of storage above the SFD, the basin can store up to $155 \mathrm{~m}^{3}$ of stormwater or approximately half of the 6 month (ARI) runoff volume. An overflow weir diverts away inflow volumes greater than this capacity.

The sand filtration unit consists of concrete masonry block walls on a reinforced concrete slab. The filter bed is divided into two compartments, which allows testing of two types of filter bed material. The sand filter bed overlays a geotextile fabric layer, which in turn covers a gravel media and an underdrain system

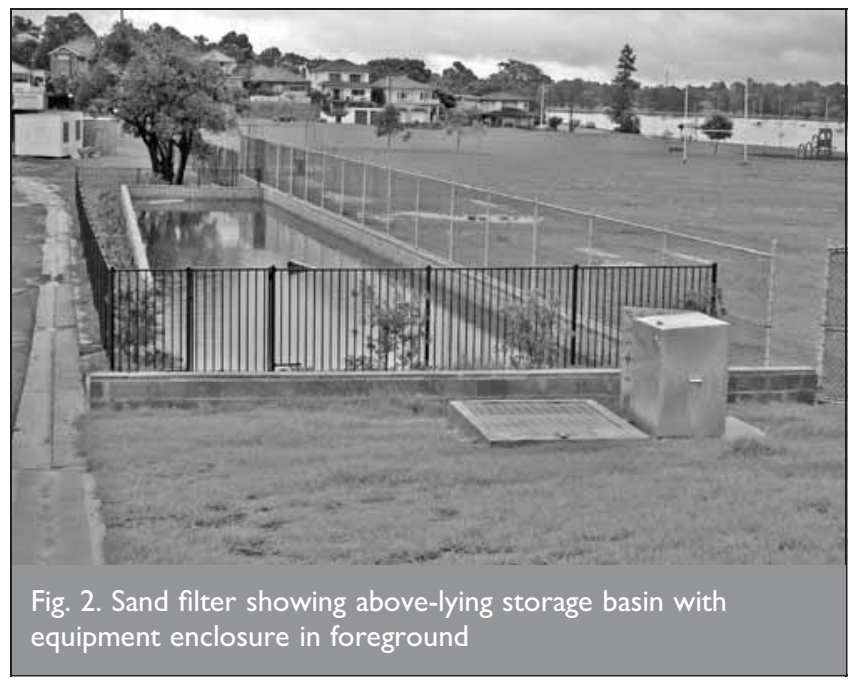

that drains filtered runoff away from the SFD. The entire sand filtration unit is covered with removable aluminium grates. In order to investigate the effect of filter media particle size and residence time in the SFD, two types of filter bed material were tested

(a) fine sand free from soil, organics and clay; 10\% passing through a $150 \mu \mathrm{m}$ sieve; $90 \%$ passing through a $300 \mu \mathrm{m}$ sieve; uniformity coefficient $d_{60} / d_{10}<3$

(b) coarse sand free from soil, organics and clay; 10\% passing through a $500 \mu \mathrm{m}$ sieve; $90 \%$ passing through a $1000 \mu \mathrm{m}$ sieve; uniformity coefficient $d_{60} / d_{10}<3$.

The downstream monitoring pit provides access for sampling of the treated water. The pit is divided so that the discharge from each SFD compartment is kept separate for monitoring purposes. The downstream monitoring pit drains back into the main stormwater trunk line.

\section{METHODS}

The pollutant removal efficiency of the SFD was determined by sampling runoff during storm events. Automatic sampling upstream of the SFD and manual grab sampling downstream were used. The automatic sampler was triggered by an acoustic Doppler velocimeter positioned in the intake pipe to the litter basket located downstream of the diversion weir. The velocity probe was placed upstream of the intake tube to reduce flow disturbances.

Manual downstream sampling was used because the attenuated outflow hydrograph of the SFD was not sufficient to trigger an automatic sampler. Also the time for water to flow through the filter, at between 8 and $9 \mathrm{~h}$, was too large to be controlled by the inflow sampler using a time delay device. This hydrological effect 
is common with stormwater sand filters and has been reported. ${ }^{6}$ The manual sampling protocol was designed specifically for the above hydrological effects.

\section{I. Analytes}

The samples were tested for: suspended solids (SS), faecal coliforms (FC), total nitrogen (TN), total Kjeldahl nitrogen (TKN), oxides of nitrogen $\left(\mathrm{NO}_{x}\right)$ comprising $\mathrm{NO}_{2}$ and $\mathrm{NO}_{3}$, total phosphorus (TP) and zinc ( $\mathrm{Zn}$ ). These parameters were chosen as representative of a broad spectrum of pollutants. ${ }^{4}$

\subsection{Sampling methodology}

The automatic sampler was programmed to use flow-proportional sampling with the trigger point being the depth of water in the intake pipe. From the collected samples event mean concentrations (EMCs) were obtained. ${ }^{7}$ Similarly, EMCs were obtained from the manual sampling undertaken at each outlet.

All samples were tested by a National Association of Testing Authorities (NATA) registered laboratory in accordance with the standard methods in the American Public Health Association, American Water Works Association and Water Environment Foundation (APHA-AWWA). ${ }^{8}$

\subsection{Infiltration testing and particle size analysis}

Within six months, the top layer of the SFD media became encrusted with fine sediments and this layer gradually grew in thickness with time and use. During a storm event when this encrusted layer was present on the media, the flow rate within the outlet pit was noticeably lower. Following raking to break up the surface of the sand bed to a depth of approximately $150 \mathrm{~mm}$, however, the flow rate increased considerably. Core samples were taken in order to perform laboratory infiltration testing and particle size analysis. Samples of the sand layer were taken when the SFD became encrusted and other samples were taken following the raking of the encrusted layer.

Constant head infiltration tests were carried out on the core samples to determine how infiltration through the two different sand types differed before and after raking of the SFD.

Particle size analyses were performed on samples taken from both the top $150 \mathrm{~mm}$ layer and the bottom layer of the filtration media to make a comparison between the amount of fines being retained within the surface layers of the filter media.

\subsection{Rainfall data}

Rainfall data were obtained from the Australian Bureau of Meteorology (BOM). The average annual rainfall for Drummoyne is $1100 \mathrm{~mm}$ with the highest mean monthly rainfall occurring in March and June, both with $132 \mathrm{~mm}$, while the lowest mean monthly rainfall is in September with $70 \mathrm{~mm}$. Rainfall data were obtained from the nearby surrounding rainfall stations at Concord (station number 066064), Observatory Hill (066062), Ashfield (066000) and Bankstown (066003). The rainfall in the catchment was estimated from isohyetal maps derived from data from these rainfall stations. These stations gave a good indication of the level of rainfall over the Drummoyne Park catchment during the monitored storm events.

Seven events were sampled between May 2001 and June 2002. The weather during winter and spring of 2001 was dry with up to
30 days between storm events. As a result, no samples were collected between May and November 2001. The weather during the remainder of the study period was mainly dry with shortduration storm events. The samples were obtained from a variety of different-sized storm events and covered both summer and winter months. The sampled storm events varied in size from 8 to $42 \mathrm{~mm}$ in rainfall depth.

In order to verify the adequacy of the sampling frequency, an analysis was undertaken of the number of samples, $n$, required using a paired sampling approach to observe a statistically significant percent difference in mean concentration. This method $^{9}$ estimates the $n$ required to have 95\% confidence in a hypothesis test given estimates of the coefficient of variance and the percent removal. The data for measured TN and $\mathrm{Zn}$ were used in the analysis. It was found in both cases that seven events were sufficient. This is largely because of the relatively high difference in the measured mean concentrations between the inlet and outlet of the SFD.

\subsection{Flow data}

The Drummoyne Park catchment draining into the filter is small (6 ha), with an average proportion imperviousness of 65\%. During dry weather there was no base flow. The largest inflow recorded at the sampler was $100 \mathrm{l} / \mathrm{s}$, which was generated from a storm event of $42 \mathrm{~mm}$ of rainfall.

\section{STORMWATER POLLUTANTS IN THE DRUMMOYNE PARK CATCHMENT}

Several studies ${ }^{4}$ have shown that high levels of pollutants accumulate on urban impervious surfaces such as roads and footpaths. These pollutants are carried into the stormwater system and include suspended solids, pathogenic micro-organisms, nutrients and heavy metals.

The constituent EMCs at the inlet are summarised in Table 1. The EMC data characterise the stormwater pollution from the catchment and are typical of urban catchments in Australian cities. ${ }^{10}$ The EMCs for mixed residential and commercial areas reported $^{11,12}$ are also presented in Table 1 . Although pollution levels can be catchment specific, there are similarities between the Drummoyne Park Catchment data and those reported in the literature. Table 1 also gives the overall pollutant removal efficiencies for the two types of SFD filter media together with comparative data. ${ }^{13,14}$

The FC concentrations entering the SFD are generally higher than in the literature (see Table 1). Higher levels are usually observed after heavy storm events when normally separate sewers overflow into stormwater systems. If sewer overflows were operating during the monitored events it would be expected that the nutrient levels and particularly the TKN levels would be elevated. High FC concentrations were measured for three of the seven events monitored. It is also possible that the high FC levels are attributable to the washing of animal (e.g. dog or bird) faeces from the park areas surrounding the SFD.

\section{I. Nutrients}

Nitrogen and phosphorus are the principal nutrients found in an aquatic system. Their levels may be elevated by inputs from a variety of sources within the catchment. Phosphorus and nitrogen can occur in the dissolved and particulate phases. Initial 


\begin{tabular}{|c|c|c|c|c|c|c|}
\hline $\begin{array}{l}\text { Water quality } \\
\text { parameter }\end{array}$ & Inlet & $\begin{array}{l}\text { Median pollutant } \\
\text { concentrations } \\
\text { for mixed } \\
\text { residential and } \\
\text { commercial } \\
\text { catchments }{ }^{11,12}\end{array}$ & $\begin{array}{l}\text { Fine filter outlet } \\
\text { (\% removal) }\end{array}$ & $\begin{array}{l}\text { Coarse filter outlet } \\
\text { (\% removal) }\end{array}$ & $\begin{array}{c}\text { Stormwater } \\
\text { filtration } \\
\text { systems }\end{array}$ & $\begin{array}{c}\text { Sand or } \\
\text { organic } \\
\text { media } \\
\text { filters }^{14}\end{array}$ \\
\hline Faecal coliforms & $\begin{array}{l}57814 \mathrm{cfu} \\
\text { per } 100 \mathrm{ml}\end{array}$ & $\begin{array}{c}\mathrm{NA}^{11} \\
7000 \mathrm{cfu} / 100 \mathrm{ml}^{12}\end{array}$ & $\begin{array}{c}20103 \text { cfu per } 100 \mathrm{ml} \\
(65 \%)\end{array}$ & $\begin{array}{c}\text { II } 966 \text { cfu per } 100 \mathrm{ml} \\
(79 \%)\end{array}$ & NA & NA \\
\hline Suspended solids & $14.4 \mathrm{mg} / \mathrm{l}$ & $\begin{array}{r}67 \mathrm{mg} / /^{11} \\
150 \mathrm{mg} / \mathrm{I}^{12}\end{array}$ & $\begin{array}{c}9.8 \mathrm{mg} / \mathrm{l} \\
(32 \%)\end{array}$ & $\begin{array}{c}3.4 \mathrm{mg} / \mathrm{l} \\
(76 \%)\end{array}$ & $81 \%$ & $66-95 \%$ \\
\hline Total phosphorus & $0.21 \mathrm{mg} / \mathrm{l}$ & $\begin{array}{l}0.26 \mathrm{mg} / \mathrm{l}^{11} \\
0.25 \mathrm{mg} / \mathrm{l}^{12}\end{array}$ & $\begin{array}{c}0.12 \mathrm{mg} / \mathrm{l} \\
(41 \%)\end{array}$ & $\begin{array}{c}0.13 \mathrm{mg} / \mathrm{l} \\
(39 \%)\end{array}$ & 45 & $4-51$ \\
\hline Total nitrogen & $2 \cdot 2 \mathrm{mg} / \mathrm{l}$ & $\begin{array}{l}1.85 \mathrm{mg} / \mathrm{I}^{11} \\
2.7 \mathrm{mg} / \mathrm{I}^{12}\end{array}$ & $\begin{array}{c}0.85 \mathrm{mg} / \mathrm{l} \\
(61 \%)\end{array}$ & $\begin{array}{c}0.86 \mathrm{mg} / \mathrm{l} \\
(61 \%)\end{array}$ & $32 \%$ & $44-47 \%$ \\
\hline Oxidised nitrogen & $\mathrm{I} \cdot \mathrm{Img} / \mathrm{l}$ & $\begin{array}{c}0.56 \mathrm{mg} / \mathrm{I}^{\prime \prime} \\
\mathrm{NA}\end{array}$ & $\begin{array}{c}0.52 \mathrm{mg} / \mathrm{l} \\
(53 \%)\end{array}$ & $\begin{array}{c}0.52 \mathrm{mg} / \mathrm{l} \\
(53 \%)\end{array}$ & -13 & $-95-22 \%$ \\
\hline Total Kjeldahl nitrogen & $\mathrm{I} \cdot \mathrm{Img} / \mathrm{l}$ & $\begin{array}{c}\mid \cdot 29 \mathrm{mg} / \mathrm{I}^{\prime \prime} \\
\mathrm{NA}\end{array}$ & $\begin{array}{c}0.33 \mathrm{mg} / \mathrm{l} \\
(70 \%)\end{array}$ & $\begin{array}{c}0.33 \mathrm{mg} / \mathrm{l} \\
(70 \%)\end{array}$ & NA & NA \\
\hline Zinc & $0.28 \mathrm{mg} / \mathrm{l}$ & $\begin{array}{l}0.15 \mathrm{mg} / /^{11} \\
0.22 \mathrm{mg} / \mathrm{l}^{12}\end{array}$ & $\begin{array}{c}0.06 \mathrm{mg} / \mathrm{l} \\
(79 \%)\end{array}$ & $\begin{array}{c}0.05 \mathrm{mg} / \mathrm{l} \\
(83 \%)\end{array}$ & $69 \%$ & NA \\
\hline
\end{tabular}

$\mathrm{NA}=$ no information available

Table I. Event mean concentrations of stormwater entering and exiting the Drummoyne SFD

investigations showed the orthophosphate levels to be very low and consequently only TP was measured in the study. The dissolved forms of nitrogen include ammonia and oxidised nitrogen. The particulate form of nitrogen in urban stormwater is mainly organic. ${ }^{10}$ TKN includes organic nitrogen and ammonia nitrogen. The source of these nutrients includes fertilisers, animal waste and detergents. Rainfall is also a significant contributor of nitrogen in stormwater discharges from atmospheric fallout. ${ }^{10}$

The average TP concentrations in the present study are lower than the means for all urban land uses reported and collated ${ }^{12}$ data from international literature and derived mean pollutant concentrations for various land uses. This is to be expected and is explained $^{15}$ as being due to the relatively low phosphorus levels in Australian soils. The soils in the Drummoyne Park catchment are part of the Lambert soils landscape group. With the exclusion of the imported landfill used in the park itself, these soils are mainly derived from Hawkesbury Sandstone.

The proportion of TKN to TN in the inflow ranged from 21 to $100 \%$, with an average of 52\%.

\subsection{Suspended solids}

Suspended solids are fine particulates suspended in water that usually have other pollutants attached to them. In the present study the EMC of SS concentrations in the inflow to the SFD was $14 \cdot 4 \mathrm{mg} / \mathrm{l}$, which is low compared with the average concentrations reported. ${ }^{12}$

\subsection{Heavy metals}

The primary sources of $\mathrm{Zn}$ are rusted metal roofs, tyre wear, motor oil and grease from roads and highways. $\mathrm{Zn}$ is a good indicator for pollution that comes from metal roofs, regional roads and commercial car-parks within the catchment. The measured $\mathrm{Zn}$ concentrations in the inflow to the SFD were marginally higher than the averages reported. ${ }^{12}$ Again, this is to be expected because of the relatively high use of galvanised metal roofs in Australia.

\section{PERFORMANCE OF SFD}

The measured water quality data in the form of a box plot are shown in Fig. 3 for the individual constituents for the inlet to the SFD and the outlets from the two filters. The black line within the box is the median value and the top and bottom of the box represent the upper and lower quartile values. The horizontal lines above and below the boxes mark the most extreme values in the sample.

Figure 3 also shows the Australian and New Zealand Environment Conservation Council ${ }^{16}$ water quality trigger values. The objective $^{16}$ is to maintain and enhance the ecological integrity of freshwater and marine ecosystems, including biological diversity, relative abundance and ecological processes. In the present study the trigger values are used for the purpose of providing a quantitative comparison of the pollutant concentrations in the effluent from the SFD. The guideline trigger values plotted in Fig. 3 are those applicable to estuaries since that is the classification of the receiving water to which the Drummoyne SFD discharges. The detection limits for each pollutant are also given in Fig. 3.

\section{I. Bacteria}

The measured FC levels varied greatly at the Drummoyne Park site. The range of results was $1600-190000 \mathrm{cfu} / 100 \mathrm{ml}$, Fig. 3. The stormwater system in this catchment, like other parts of Sydney, is normally separate but in heavier rainfall events sewage overflows into the stormwater system resulting in larger FC levels. During four rainfall events FC counts in the inflow to the SFD were low, inferring sewer overflows were not operational. During these events the count in the inflow was also below the trigger value $^{16}$ for secondary contact recreational activities. During three other events FC counts in the inflow to the SFD were high, indicating sewer overflows were likely. For this type of event the 


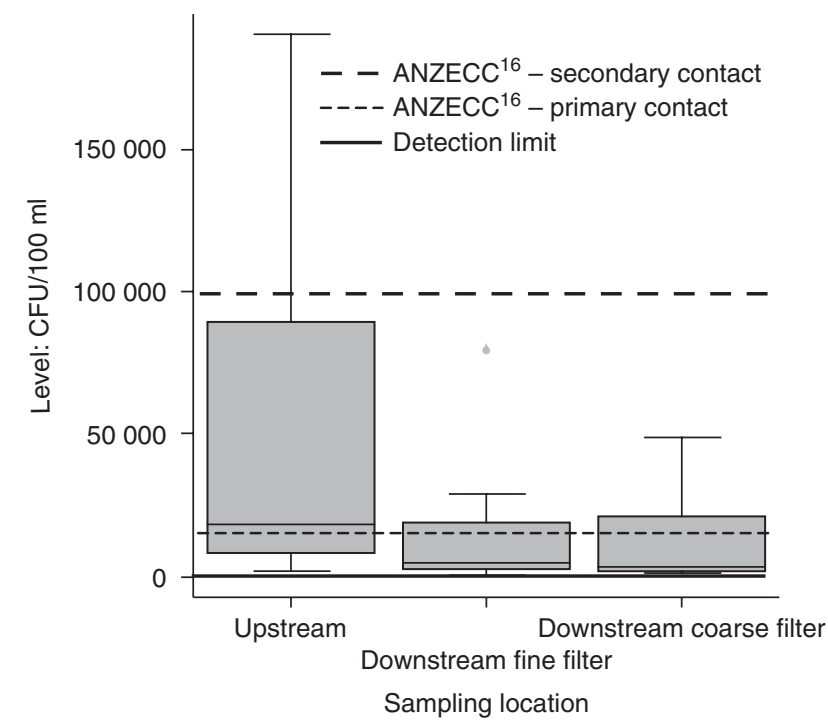

(a)

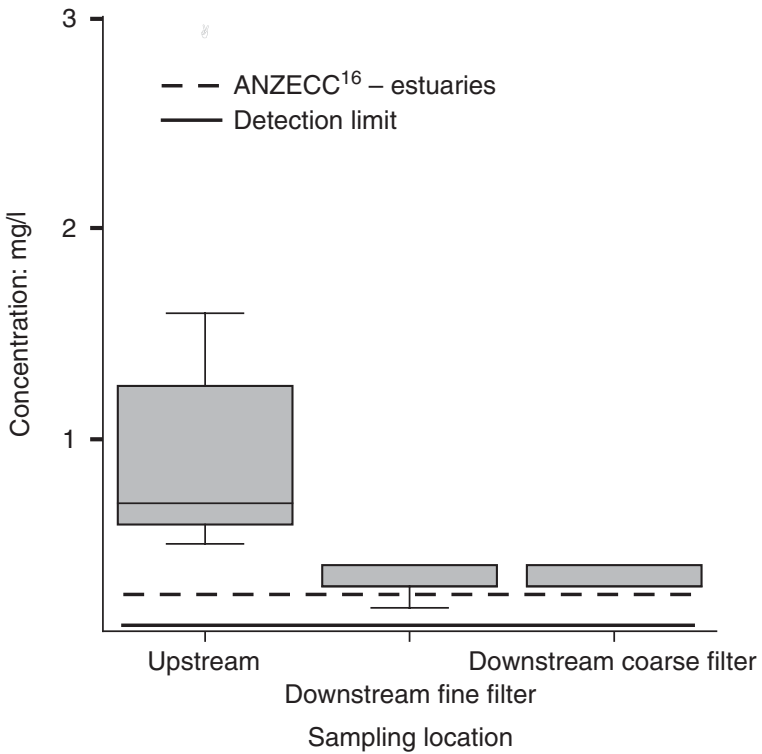

(c)

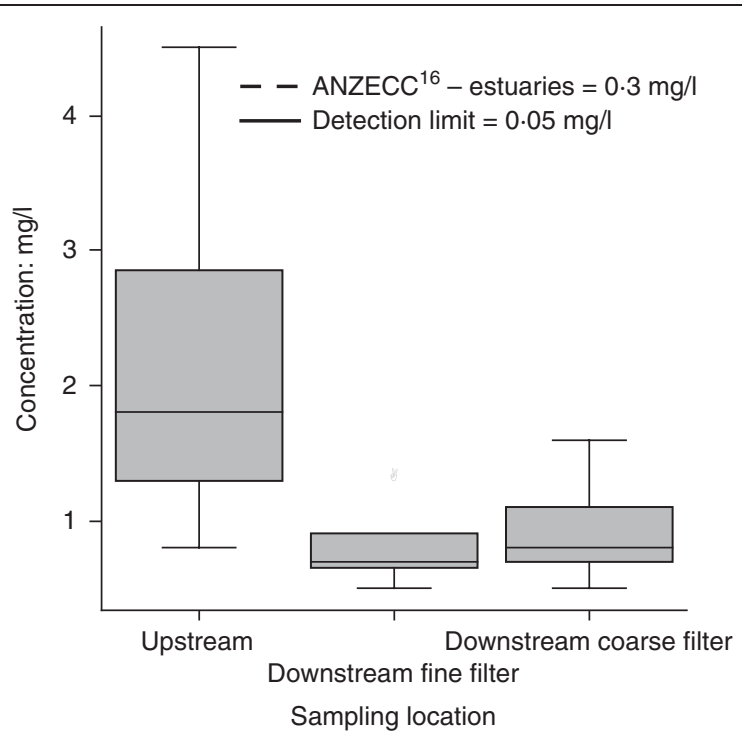

(b)

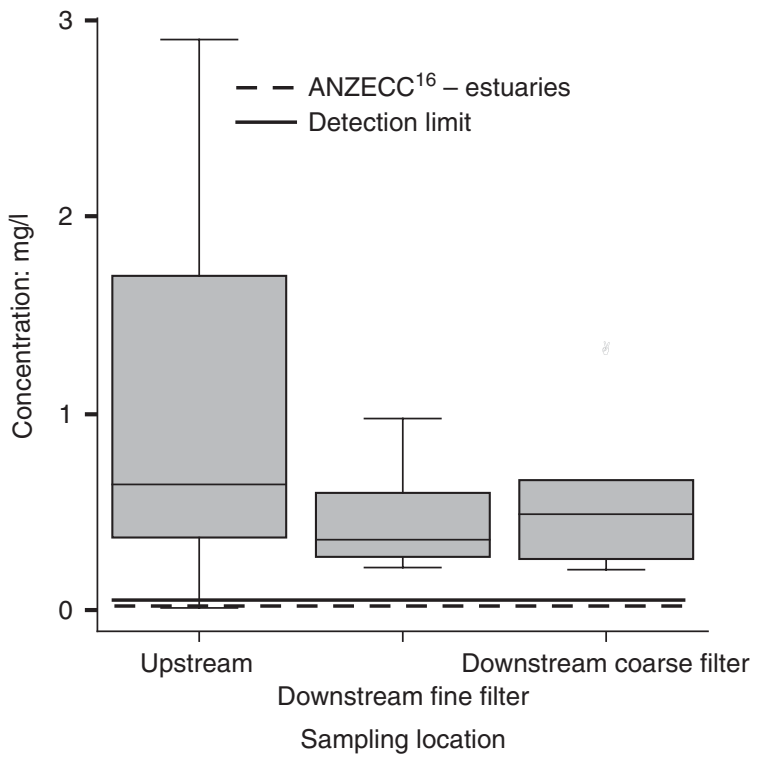

(d)

Fig. 3. Box plots for pollutant concentrations upstream and downstream of the SFD: (a) FCs; (b) TN; (c) TKN; (d) NO ; (e) TP; (f) SS; and (g) $\mathrm{Zn}$

management of stormwater quality should include improvements to the sewerage system rather than relying on stormwater treatment measures such as the SFD.

Figure 3 shows that effluent from the SFD meets the trigger value $^{16}$ for primary and secondary contact criteria for all median values, although some measured effluent values exceed the primary contact criterion. These events correspond to when FC counts in the inflow to the SFD were high and sewer overflows were likely. Overall the percentage reduction of FCs in the stormwater was $65 \%$ for the fine filter media and 79\% for the coarse media.

\subsection{Nutrients}

Figure 3 shows that the two filter media performed very similarly for the removal of all types of nitrogen. The EMC of TN and TKN levels discharged from the SFD was $0.86 \mathrm{mg} / \mathrm{l}$ and $0.33 \mathrm{mg} / \mathrm{l}$ respectively, Table 1 . The SFD removed, $61 \%$ of TN, $70 \%$ of TKN and $53 \%$ of $\mathrm{NO}_{x}$ from the stormwater runoff. The SFD generally performed better for removal of $\mathrm{TN}$ and $\mathrm{NO}_{x}$ than reported in the literature, Table 1 . The concentrations of $\mathrm{TN}$ and $\mathrm{NO}_{x}$ for all monitored rainfall events were, however, above the trigger value ${ }^{16}$ for estuaries. The concentration of TKN was slightly above the trigger value, ${ }^{16}$ Table 1 and Fig. 3.

The EMC of TP in the treated stormwater is $0 \cdot 12-0 \cdot 13 \mathrm{mg} / \mathrm{l}$, Table 1 . The SFD achieved a 40\% reduction in TP and was similar to values reported in the literature. Fig. 3 shows that the concentrations of TP for all monitored rainfall events were above the trigger value ${ }^{16}$ for estuaries.

\subsection{Suspended solids}

Overall the coarse filter afforded a reduction of 75\% in SS concentrations in the outflow from the SFD, Table 1. The average removal efficiency for the fine filter was lower at 32\%, Table 1. This is attributed to initial flushing of contaminant fines from the sand filter. The first few events had a high suspended solids load and in one event the concentration in the 


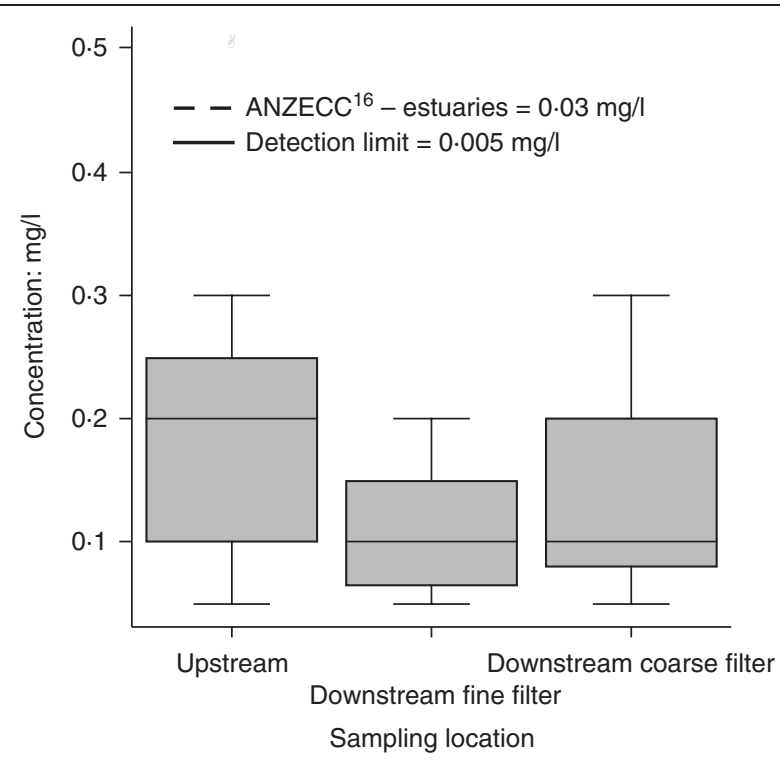

(e)

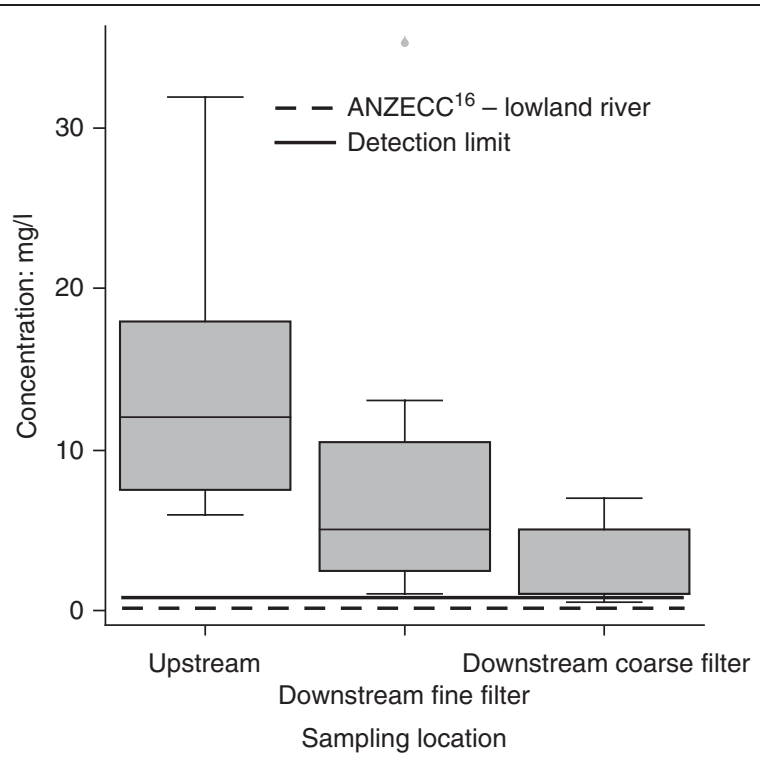

(f)

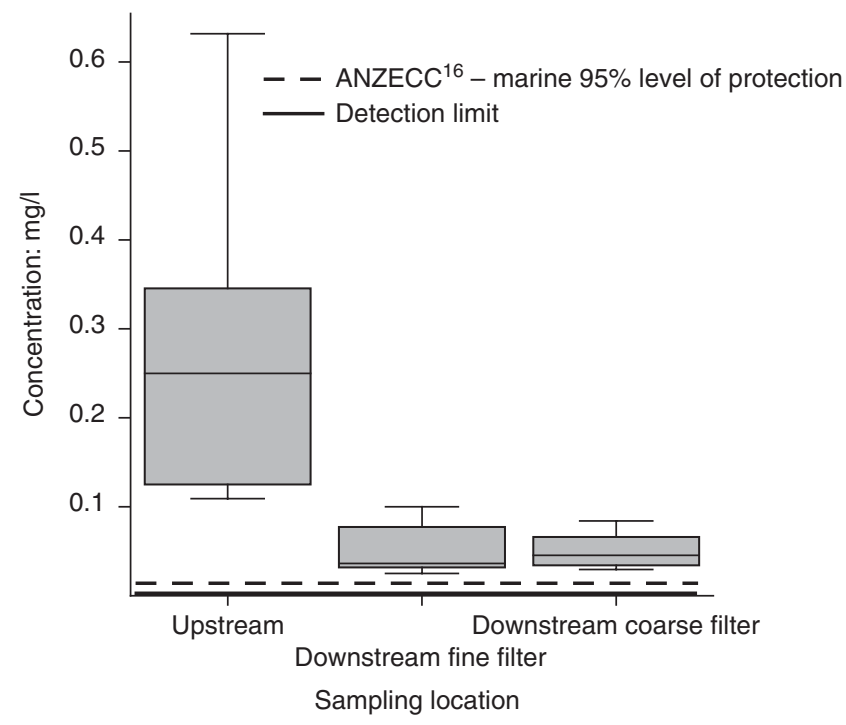

(g)

Fig. 3. Continued

outflow exceeded that in the inflow. For later events the filter performed similarly to the coarse sand filter. Fig. 3 shows that the concentrations of SS for all monitored rainfall events were above the trigger value ${ }^{16}$ for lowland rivers. There are no trigger values ${ }^{16}$ for estuaries.

\subsection{Heavy metals}

The EMC of $\mathrm{Zn}$ in the outflows from the filter was 0.05$0.06 \mathrm{mg} / \mathrm{l}$, Table 1 . The concentrations of $\mathrm{Zn}$ for all monitored rainfall events were above the trigger value ${ }^{16}$ for a $95 \%$ level of protection for marine waters, Fig. 3. This protection level signifies the percentage of species expected to be protected. The marine water classification for heavy metals is typically used for estuaries.

The filter removed $80 \%$ of $\mathrm{Zn}$ in the stormwater runoff, see Table 1, with both sand media filters producing near identical results. The SFD performed well for the removal of $\mathrm{Zn}$ from the stormflow and the device appears efficient at consistently removing a large proportion of $\mathrm{Zn}$.

\subsection{Summary}

The performance of the SFD is good and is generally better than reported in literature, Table 1 . The concentration of pollutants in the effluent is, however, still usually above water quality trigger ${ }^{16}$ values. If a better quality effluent is required then additional treatment upstream of the SFD is necessary.

\section{COMPARATIVE PERFORMANCE OF SFD}

Table 1 shows that the pollutant removal rates are similar or better than those rates published. ${ }^{13,14}$ The exception is the removal rate of SS for the fine filter as explained in the preceding section.

The data collected for TN, TP and SS in the present study were compared with data available in the literature in Figs 4(a)-4(c). The data from the literature were collated and published in Ref. 17.

\section{I. Total nitrogen}

Figure 4(a) shows a comparison of TN data collected from this study and those available in the literature. This shows the relationship between the concentration of TN at the outlet expressed as a 


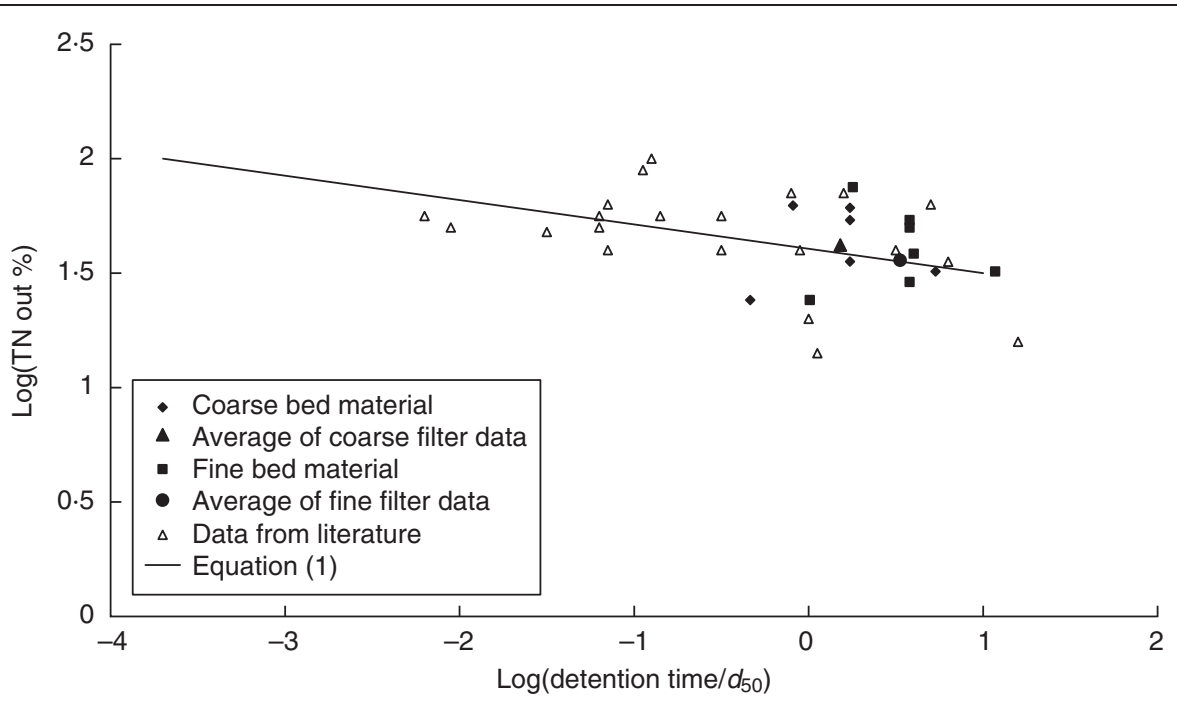

(a)

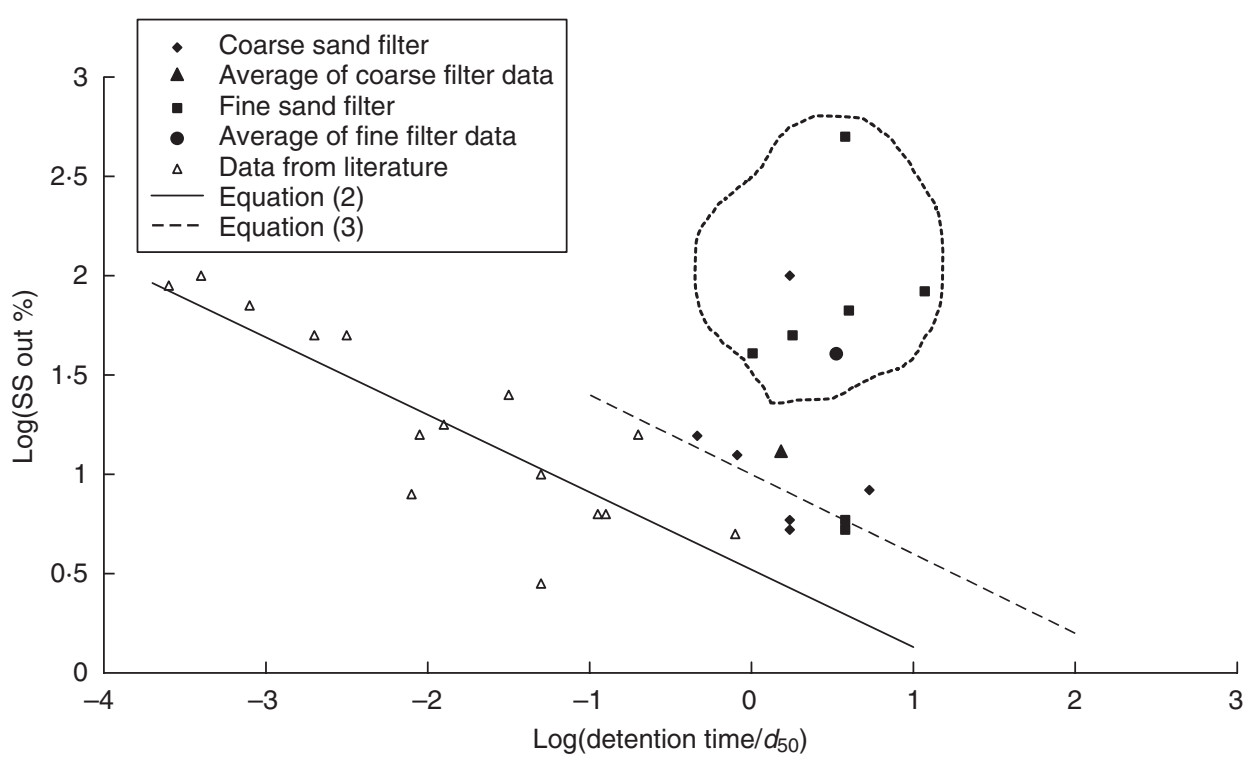

(b)

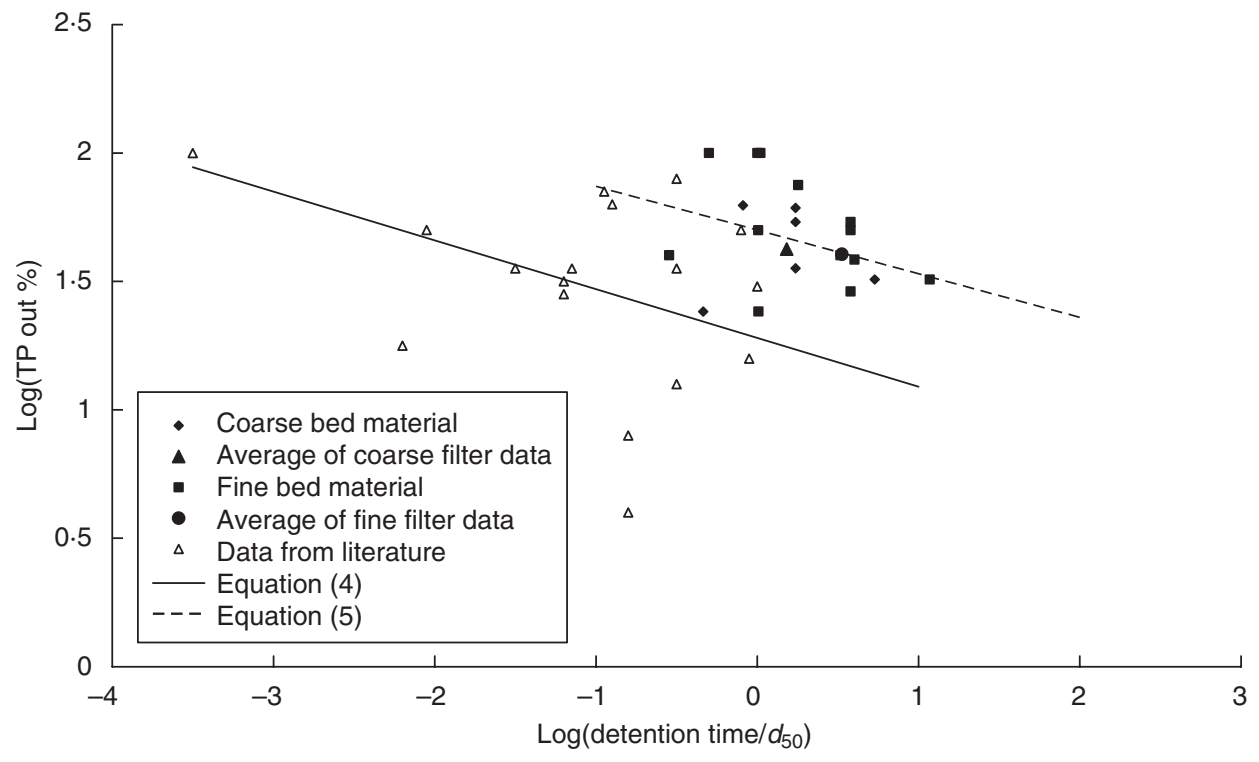

(c) 
percentage of the concentration levels of the inflow data, that is the pollutant removal performance and the ratio of the detention time to median particle size $\left(d_{50}\right)$. This ratio is used in the MUSIC software to estimate the water quality treatment performance of soil filters. MUSIC is decision support software that is typically used to assess the performance of best management practice systems and is widely used in Australia. Also plotted on Fig. 4(a) is the relationship used in the MUSIC software application, ${ }^{17}$ equation (1)

$\log (\mathrm{TN}$ output $\%)=1 \cdot 62-0 \cdot 10 \log \left(\right.$ detention time $\left./ d_{50}\right)$

where TN output $\%$ is the concentration of TN of the effluent expressed as a percentage of the concentration of the inflow. Detention time is the time in days that the stormwater is in storage above the sand filter as it percolates through the filter. $d_{50}$ is the median particle size of the sand used in the filter.

Figure 4(a) shows a reasonable agreement between the data collected in this study and those reported in the literature. Further, the average values of the data for the present study show a good agreement with equation (1).

\subsection{Suspended solids}

Figure 4(b) shows a comparison of SS data collected from this study and those available in the literature. Also plotted is the relation used in MUSIC, ${ }^{17}$ equation (2). $\log ($ SS output $\%)=0.52-0.39 \log \left(\right.$ detention time $\left./ d_{50}\right)$

where SS output \% is the concentration of SS of the effluent expressed as a percentage of the concentration of the inflow. Fig. 4 (b) shows that for most events the concentrations of SS discharged from the fine filter, shown encircled by a dotted line, do not fit the rest of the data for reasons explained in the previous section. The data for the coarse filter fit better with data from the literature, although they plot towards the upper bound within the data range. Equation (3) was formulated to better represent the data collected from the present study, excluding the data shown encircled in Fig. 4(b). This equation also gives an upper boundary to the data from the literature and can be viewed as a conservative representation of those data.
$3 \log ($ SS output $\%)=1 \cdot 00-0 \cdot 40 \log \left(\right.$ detention time $\left./ d_{50}\right)$

The adequacy of equations (2) and (3) requires further investigation because of the uncertainty inherent in the data from the fine filter.

\subsection{Total phosphorus}

Figure 4(c) shows a comparison of TP data collected from this study and those available in the literature. Also plotted is the relation used in MUSIC, ${ }^{17}$ equation (4).

$4 \quad \log ($ TP output $\%)=1 \cdot 28-0 \cdot 19 \log \left(\right.$ detention time $\left./ d_{50}\right)$

Figure 4(c) shows that the scatter for all data is large and that the data from the present study plot towards the upper bound within the data range. Equation (5) was formulated to represent better the data collected from the present study. This equation also gives an upper bound to the data from the literature and may be viewed as a conservative representation of those data. The scatter in the data is, however, too wide for a good representation.

$5 \quad \log ($ TP output $\%)=1 \cdot 87-0 \cdot 17 \log \left(\right.$ detention time $\left./ d_{50}\right)$

In general the data are not well represented by equations (4) or (5) and the removal process for TP is not adequately described by the parameters of equations (4) or (5). The assessment was based on physical characteristics that were able to be measured in this field study, for example detention time and $d_{50}$. It is apparent that these parameters alone cannot fully describe the pollution removal process. A more complete description of the removal process including chemical and biological processes requires laboratory studies. Further research is necessary to study the mechanism by which SFDs remove TP and to isolate the principal parameters that describe these processes.

\section{LONG-TERM PERFORMANCE OF SFD AND FILTER MEDIA LIFE}

During the operation of the SFD a layer of fine organic material developed on the SFD and this subsequently formed an encrusted layer. Fig. 5 shows the reduction in infiltration as a

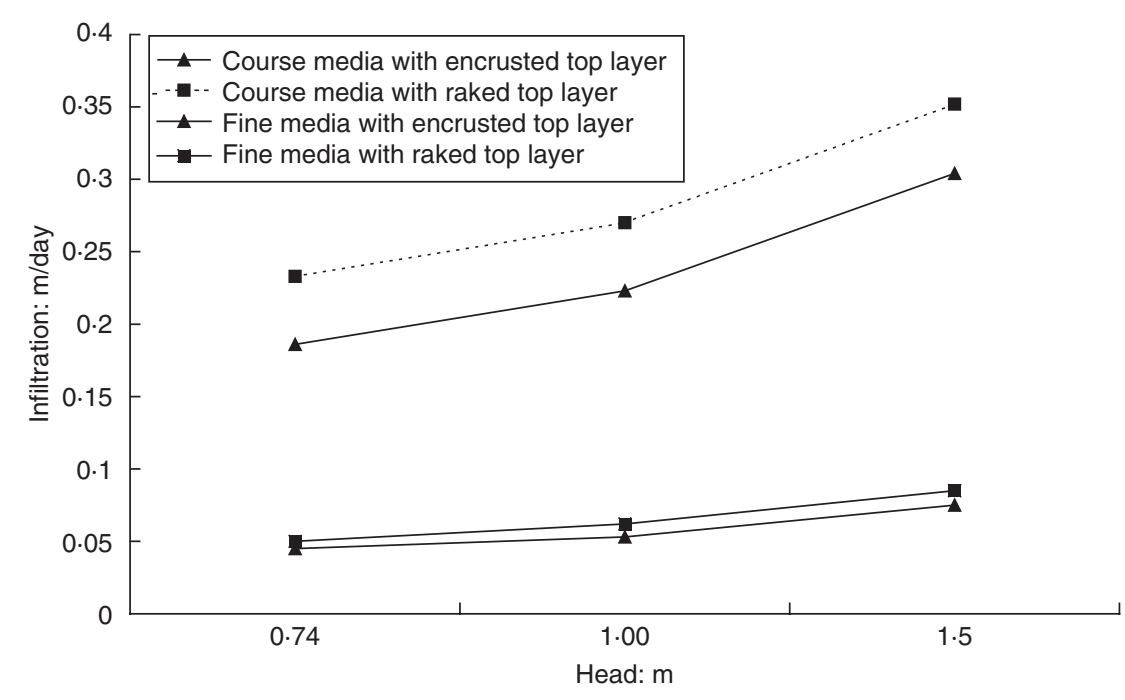




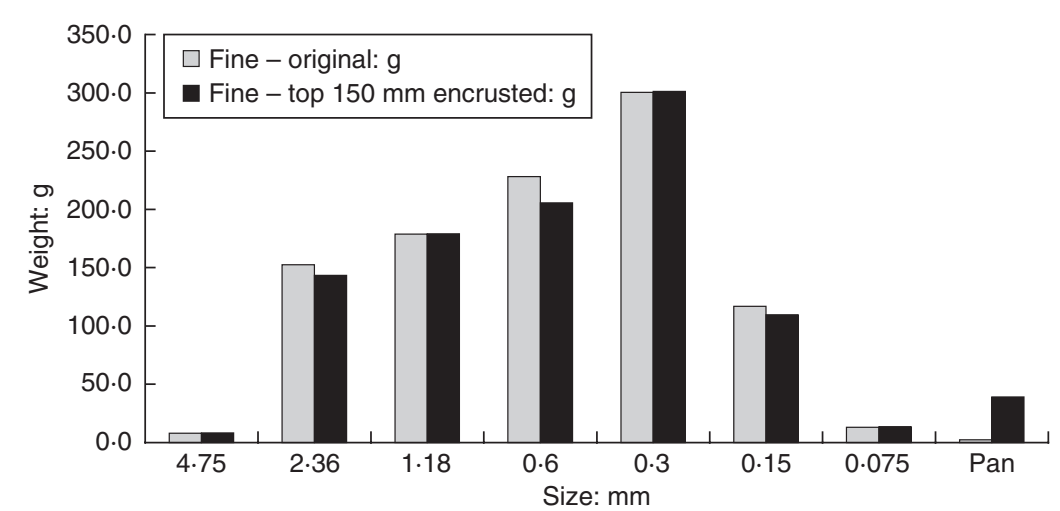

(a)

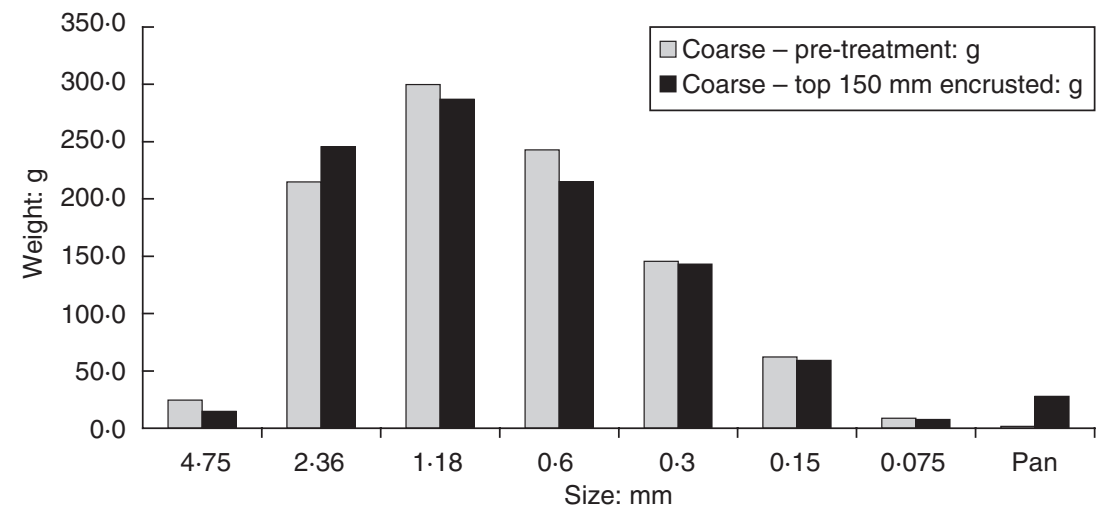

(b)

Fig. 6. Comparison between pre- and post-treatment: (a) fine sand media, (b) coarse sand media

result of the encrustation compared with those values following raking. The flow rate of the fine media was four times less than the discharge through the coarse media. The coarse filter was severely affected by the development of the encrusted layer and this caused the discharge to be reduced by $20 \%$, Fig. 5 . By contrast the fine sand filter was affected, but the discharge reduced by only a few percent when the encrustation developed on this filter. This could be owing to the smaller relative difference in permeability between the crust and the fine sand.

Figure 6 shows that there is a significant increase in the amount of 'pan' fines. The retention of the fines represents the build-up of pollutants trapped within the filter media. Monitoring the build-up of the fines throughout the depth of the filter media together with a comparison of the performance of the filter media presents a way of determining the useful life of the SFD media before it needs to be replaced. Long-term monitoring is required to define properly an appropriate maintenance regime. ${ }^{18}$ At the time of writing this paper the SFD had been in place for 6 years and was still performing well. No replacement of the sand media was required during this time and raking was the only maintenance required on a regular basis.

\section{CONCLUSIONS}

The removal rates for both types of filter media were generally greater than reported previously for sand filters. There was, however, little difference between the two media types, except for SS removal. In terms of modelling the system performance, it was found that the existing empirical models did not provide accurate predictions of some pollutant removal efficiencies. Additional equations were developed to describe better the suspended solids and total phosphorus removal rates measured in this study. It was, however, concluded that future research should focus on developing a greater understanding of the individual pollutant retention process occurring within the sand filter. The study has shown that a fine organic crusting layer gradually builds up on the surface of the filter and this reduces the through-flow by up to $20 \%$ over 6 months of use. Regular raking of the top $150 \mathrm{~mm}$ layer, however, eliminates this flow impedance.

\section{ACKNOWLEDGEMENTS}

The authors are grateful to the New South Wales Environment Protection Authority (NSW EPA) Stormwater Trust for funding this study. They are also grateful to George Angelis, Stormwater Manager, City of Canada Bay Council for extensive assistance and support with this investigation.

\section{REFERENCES}

1. BeEChAm S. Water sensitive urban design: a technological assessment, Waterfall. Journal of the Stormwater Industry Association, 2003, 17, No. 1, 5-13.

2. URbonAs B. R. Design of a sand filter for stormwater quality enhancement. Water Environment Research, 1999, 71, No. 1, 102-113.

3. Beecham S., Kandasamy J., Khiadani M. and Trinh D. Modelling on-site detention on a catchment-wide basis. Urban Water Journal, 2005, 2, No. 1, 23-32.

4. DAVIS A. Green-engineering principles promote low-impact development. Environmental Science and Technology, American Chemical Society, 2005, 39, No. 16, 339A-344A. 
5. Krajewski B. J., Chebbo G. and Saget A. Distribution of pollutant mass vs volume in stormwater discharges and the first flush phenomenon. Water Resources, 1998, 32, No. 8, 2341-2356.

6. Dunphy A., Beecham S., Vigneswaran S., Ngo H. H., McLaughlan R. and Collins A. Development of a confined water sensitive urban design (WSUD) system using engineered soils. Journal of Water Science and Technology, 2007, 55, No. 4, 211-218.

7. Randall J., Charbeneau M. and Barrett E. Evaluation of methods for estimating stormwater pollutant loads. Water Environment Research, 1998, 70, No. 7, 1295-1302.

8. American Public Health Association, American Water Works Association and Water EnVIRonment Foundation (APHAAWWA). Standard Methods for the Examination of Water and Wastewater, 19th edn. APHA, Washington, 1995.

9. GeoSyntec Consultants and Urban Drainage and Flood Control District and Urban Water Resources Council of ASCE. Urban Stormwater BMP Performance Monitoring: A Guidance Manual for Meeting the National Stormwater BMP Database Requirements. US Environmental Protection Agency, Office of Water, Washington, DC, 2002, EPA 821/ B-02/001.

10. Chiew F. H., Mudgway B. L., Duncan H. P. and McMahon T. A. Urban Stormwater Pollution-Industry Report. Cooperative Research Centre for Catchment Hydrology, Melbourne, Australia, 1997, Report 97/5.

11. United States Environmental Protection Agency. NPDES Stormwater Sampling Guidance Manual. CK Smoley/CRC Press, Boca Raton, Florida, 1993.
12. Duncan H. Urban stormwater pollutant concentrations and loads. Australian Runoff Quality (Wong T. H. F. (ed.)). Institution of Engineers, Sydney, Australia, 2005, Ch. 3.

13. Brown W. and SchUeler T. National Pollutant Removal Performance Database of Current Urban Stormwater Best Management Practices. Center for Watershed Protection, Ellicott City, Maryland, 1997.

14. Muthukrishnan S., Madge B., Selvakumar A., Field R. and Sullivan D. The Use of Best Management Practices (BMPs) in Urban Watersheds. United States Environmental Protection Agency (US EPA), 2004, Report No. EPA/600/ R-04/184.

15. Mudghay L. B., Duncan H. P., McMahon T. A. and Chiew F. H. S. Best Practice Environmental Management Guidelines for Urban Stormwater. Cooperative Research Centre for Catchment Hydrology, Melbourne, Australia, 1997, Report 97/7.

16. Agriculture and Resource Management Council of Australia and New Zealand/Australian and New Zealand Environment AND ConsERVATION CouncIL (ANZECC). National Water Quality Management Strategy-Australian and New Zealand Guidelines for Fresh and Marine Water Quality. ANZECC, 2000, ISBN 0957824505.

17. CRCCH. Manual for MUSIC Version 3. CRC for Catchment Hydrology, Melbourne, Australia, 2005.

18. BARRETT M. E. Performance, cost and maintenance requirements of Austin sand filters. Water Resources Planning and Management, ASCE, 2003, 129, No. 3, 234-242.

\section{What do you think?}

To comment on this paper, please email up to 500 words to the editor at journals@ice.org.uk

Proceedings journals rely entirely on contributions sent in by civil engineers and related professionals, academics and students. Papers should be $2000-5000$ words long, with adequate illustrations and references. Please visit www.thomastelford.com/journals for author guidelines and further details. 